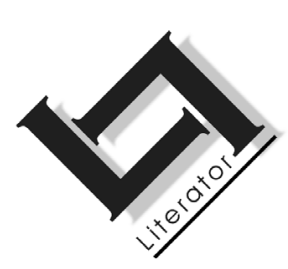

\title{
Afrikaanse vryheidsliedjies as herkonstruksie van Afrikaneridentiteit: 'n ideologies-kritiese perspektief ${ }^{1}$
}

\author{
L. Lambrechts \& M. Viljoen \\ Departement Musiek \\ Universiteit van die Vrystaat \\ BLOEMFONTEIN \\ E-pos: lizabe.lambrechts@gmail.com \\ viljoenM.hum@ufs.ac.za
}

\begin{abstract}
Afrikaans freedom songs as a reconstruction of Afrikaner identity

Media polemics that centred on Afrikaner identity and language proliferated in Afrikaans newspapers of the early 2000s. It illustrates that although more than a decade has passed since democratisation, identity politics are still an important South African topic and renegotiation therefore continues. This article discusses the role of Afrikaans freedom songs as a reconstruction of white Afrikaner identity with the specific aim of establishing a point of departure for an ideology-critical theorising of the topic. In this regard, the interpretative tools of metaphor analysis and ideology critique of Johann Visagie (1996) are applied within the broader framework of the so-called Critical Theory. The five dominant postapartheid narratives recorded by Melissa Steyn (2001) serve as starting point for this study. The selection of freedom songs is related to specific constructions of "whiteness" portrayed in the mentioned narratives.
\end{abstract}

1 Hierdie artikel is gepubliseer vanuit die Meestergraad-verhandeling getiteld, Afrikaanse vryheidsliedjies as konfigurasie van identiteit: 'n ideologie-kritiese perspektief, voltooi in 2008 aan die Departement Musiek, Universiteit van die Vrystaat. 


\section{Opsomming}

\section{Afrikaanse vryheidsliedjies as herkonstruksie van Afrikaneridentiteit}

Mediapolemiek rondom Afrikaner identiteit en taal het die Afrikaanse koerante in die vroeë jare van die nuwe millennium gedomineer. Dit illustreer dat identiteitspolitiek meer as 'n dekade ná demokratisering steeds uiters aktueel in Suid-Afrika is en dat die heronderhandeling daarvan nog 'n voortgaande proses is. In hierdie artikel word stilgestaan by die rol van Afrikaanse vryheidsliedjies as herkonstruksie van wit identiteit, terwyl dit meer spesifiek ten doel het om 'n vertrekpunt daar te stel vir 'n ideologies-kritiese teoretisering van die onderwerp. In hierdie opsig word binne die breër raamwerk van die sogenaamde Kritiese Teorie gebruik gemaak van Johann Visagie (1996) se interpretatiewe werktuie, metafooranalise en ideologiekritiek. 'n Belangrike vertrekpunt vir hierdie ondersoek is vyf dominante postapartheidsnarratiewe, soos opgeteken deur Melissa Steyn (2001). 'n Seleksie van vryheidsliedjies word by spesifieke konstruksies van "witheid" betrek, soos wat in die genoemde narratiewe uitgebeeld is.

\section{Inleiding}

Het lied is in het volksleven innig verbonden met het dagelijks bestaan. In hun verruimde betekenis alz zang, vertolken melodie en ritme [...] al wat hart en zinnen beroert [...] Zingen is zelfexpressie sonder meer, is tevens mededeling van hart tot hart; met ander woorden: zang is een gemoedsuitstraling. (Gelber, 1982:7-8.)

Soos duidelik uit die huidige mediapolemiek oor die laaste dekade en 'n half blyk, hou postapartheid Suid-Afrika diepgaande psigologiese aanpassings vir Suid-Afrikaners in - veral vir wit Afrikaanssprekendes wat sin probeer maak van hulle plek en funksie in 'n veranderende samelewing. Sentraal tot hierdie vraagstuk staan die kwessie van identiteit. Hoewel die dood van identiteitspolitiek reeds by herhaling in internasionale literatuur aangekondig is, $\mathbf{2}$ is postapartheid Suid-Afrika 'n vrugbare teelaarde vir studie op hierdie gebied, soos wat onder meer uit resente plaaslike musikologiese studies gesien kan word. ${ }^{3}$ Uit die innige verknooptheid van musiek met

2 'n Spesiale uitgawe van die New literary history (Albertini et al., 2000) is in die geheel gewy aan die vraag: "Is daar lewe ná identiteitspolitiek?"

3 Sien onder andere die artikels van Brett Pyper (2005) wat jazz as 'n kragtige metafoor vir swart Suid-Afrikaanse identiteit gedurende apartheid belig, asook 
die daaglikse bestaan van mense (vgl. Gelber, 1982 hierbo), volg die kardinale belang van veral hermeneutiese studies. Die gebied van populêre wit Afrikaanse musiek is egter nog nie genoegsaam ondersoek nie, en onlangse voorbeelde hiervan noodsaak ook verdere aandag.

In hierdie artikel word stilgestaan by die rol van Afrikaanse vryheidsliedjies 4 as herkonstruksies van Afrikaneridentiteit, terwyl dit meer spesifiek ten doel het om 'n vertrekpunt vir 'n ideologies-kritiese teoretisering van die onderwerp daar te stel. 5 In hierdie opsig word binne die breër raamwerk van die sogenaamde Kritiese Teorie gebruik gemaak van Johann Visagie (1996) se interpretatiewe werktuie, naamlik metafooranalise en ideologiekritiek. Visagie formuleer ideologie as 'n negatiewe verskynsel 6 en hierdie siening hang saam met sy idee van die "hipernorm", 7 wat op die outonomisering (oormatige bevoordeling of selfs "verafgoding") van sekere waardes fokus.

Mary Robertson (2004) se studie wat die rol van populêre musiek in die onderhandeling van wit Suid-Afrikaanse identiteit ondersoek. Hierteenoor redeneer Shirli Gilbert (2005a) dat liedjies as 'n ruimte funksioneer waarbinne diegene wat eers gemarginaliseer is ' $n$ stem kan vind om hulle identiteit en ervarings uit te druk, terwyl Lara Allen (2005) die fundamenteel-hibriede en konstant-veranderende aard van populêre swart Suid-Afrikaanse musiek ondersoek.

$4 \quad$ Binne die konteks van hierdie artikel verstaan ons die begrip vryheidsliedjie nie in die enger sin van 'n politiese lied wat in protes teen 'n onderdrukkende gemeenskap of regering gesing word nie. In aansluiting by Asante en Mazama (2005:250), word vryheidsliedjies eerder beskou as uitings van kollektiewe protes, self-bevestiging, inspirasie en bemoediging.

5 'n Belangrike studie van postapartheidsidentiteit wat steun op postrukturalistiese teorie en meer spesifiek op die psigolanalitiese denke van Jacques Lacan, is Bert Olivier (2006) se analise van die kompleksiteit van identiteit in demokrasie. Olivier dui op die futiliteit van 'n monolitiese identiteitsbegrip en skets die ontvouing van 'n historiese identiteitshersiening aan die hand van Lacan se subjekteorie.

$6 \quad$ Hierdie is in navolging van die Marxistiese tradisie, dit wil sê in kontras met die hantering van ideologie as 'n neutrale term wat bloot op iets soos 'n bepalende "lewensbeskouing" sou dui.

$7 \quad$ Die hipernorm (Visagie, 1994; 1996) is 'n metodologiese instrument, waarmee dominasieverhoudings binne ' $n$ ideologies-kritiese diskoersanalise blootgelê kan word, en waardeur ideologiese verwrongenheid na die oppervlak gebring word. In terme van botsende ideologiese "verbintenisse" sou 'n dergelike analise dien tot 'n spekulatiewe begronding van watter tekstuele parameter (lirieke of musiek, in hierdie geval) "die waarheid praat", of in Visagie se terme, betekenis oorheers (vgl. ook Viljoen, 2005:78-79). 
Deur middel van die bestudering en bespreking van 'n seleksie van Afrikaanse vryheidsliedjies, 8 wil hierdie artikel die relevansie van hierdie teoretiese konstruk vir die onderwerp ondersoek. 'n Belangrike vertrekpunt in hierdie verband is vyf dominante postapartheidsnarratiewe, soos opgeteken deur Melissa Steyn (2001), waarin elke narratief ' $n$ bepaalde konstruksie van wit postapartheidsidentiteit skets. 'n Seleksie van vryheidsliedjies sal gevolglik betrek word by konstruksies van "witheid", soos uitgebeeld in Steyn (2001) se narratiewe. Eerstens word daar kortliks stilgestaan by wit Afrikaanssprekende identiteit as onstabiele konstruk. ${ }^{9}$

\section{Afrikaneridentiteit as onstabiele konstruk}

Soos ' $n$ anonieme filosoof dit stel, is die voortdurende kulturele akkulturasie van Afrikanerskap nie alleenlik eie aan die nuwe SuidAfrika nie, maar was die Afrikaner ook nog altyd besig om te verander. Uit hierdie perspektief is die hele geskiedenis van Afrikaansheid immers "' $n$ verhaal van dinamika, van komplekse oorspronge, onverwagte wendings en onwaarskynlike kombinasies, die huidige onstabiliteit is bloot weer 'n nuwe stroomversnelling van dié proses, wat Afrikaners opnuut voor die uitdaging van selfontdekking te staan bring" (Anon., 2001).

In postapartheid Suid-Afrika voel baie Afrikaners egter uitermate gemarginaliseerd en kwesbaar (vgl. Roodt, 2006:18; De Klerk, 2007: 6). Ook hierdie gewaarwording kan na die verlede herlei word:

Die tydperk van Afrikanermag (1948-1994) [was] eintlik 'n uitsondering in die geskiedenis van die Afrikaners. As 'n mens teruggaan na die vroeëre geskiedenis van die Afrikaners, dan was hulle as 'n minderheidsgroep dikwels marginaal en magteloos. Dit was 'n situasie waar 'n boer 'n plan moes maak, moes akkommodeer en by wyse van alliansie op allerlei maniere 'n weg in 'n groter konteks vind waar daar imperiale maghebbers en meer getalryke groeperings was. (Du Toit aangehaal deur Anon., 2001:11.)

8 Opregte dank aan die gemeenskapsradiostasie, Radio Rosestad, vir vrye toegang tot hulle argief.

$9 \quad$ Afrikaner word nie in hierdie artikel as uitruilbaar met Afrikaanssprekend gebruik nie, hoewel hierdie studie sensitief daarteenoor staan dat laasgenoemde begrip mense van kleur insluit. In hierdie artikel word gefokus op "Afrikanerskap" soos dit in die openbare polemiek gerepresenteer word. 
Wit Suid-Afrikaners as 'n minderheidsgroep is grootliks 'n "permanente" groep, nie as oorsponklike inwoners van die land nie, maar wel as 'n sosiologies-inheemse bevolksingsgroep (Steyn, 2001: xxiv). Op grond hiervan kan hulle sterk aanspraak maak op wettige "saambewonerskap" van die land (Steyn, 2001:xxxiv). Baie wit SuidAfrikaners het daarom 'n diepe verbondenheid met die land en Afrikaners het weinig bande met die lande van hulle etniese oorsprong behou (Giliomee, 2003:xiv).

Gevoelens van "tuiste" en van "behoort" word egter gekompliseer deur die verwikkelde prosesse van postkolonialisme, omdat die Afrikaner by geleentheid gekoloniseer is, maar ook die beoefenaar van kolonialisme en neokolonialisme was. Hierdie prosesse is te wyte aan die komplekse prosesse van okkupasie en inbesitneming, asook verskillende vorms van interne kolonisasie (Van der Merwe, 2003:11).

In hierdie lig gesien, is dit interessant om daarop te let dat daar onlangs onder wit Afrikaners magsdruk uit 'n belangegroep ontstaan het wat opnuut een oorkoepelende identiteit vir alle Afrikaners wil skep. Hierdie beweging, wat die "Neo-Afrikaanse Protesbeweging" (hierna NAP) genoem sou kon word, 10 hanteer identiteitsvraagstukke by wyse van 'n magsdiskoers; 'n diskoers wat gerig is tot die regering, eerder as tot Afrikanerlandsgenote. Die NAP (wat hoofsaaklik uit 'n groepering van wit, intellektuele mans bestaan) praat namens die intelligente "nuwe" Afrikaanssprekende en so word 'n postapartheidAfrikanerdiskoers kunsmatig geskep.

Die NAP voed hierdie diskoerse hoofsaaklik deur koerantrubrieke, en gebruik taal en kultuur (soos onderskeidelik bevorder deur taalaktiviste en kultuurvegters) om hulle stryd teen integrasie te regverdig (Van der Merwe, 2008).11 Hierdie skrywers maak ook gereeld beduidend gebruik van strydmetafore ${ }^{12}$ soos "die Afrikaner word geviktimiseer" (Roodt, 2006:18), "hulle probeer ons terugkry vir apartheid" (Maree aangehaal in Fitzpatrick, 2007), "ons moet veg vir ons

10 Hierdie konsep is aanvanklik geformuleer deur Johann Visagie (1996).

11 Vergelyk die laaste afdeling van hierdie artikel vir kritiese kommentaar op die standpunt van die NAP.

12 In hierdie verband is dit interessant om te let op soortgelyke metafore wat tydens die apartheidsera se politieke diskoerse in koerante soos Rapport, Beeld, en Die Burger oorheers het. Dirven (1994:174) identifiseer sommige van hierdie metafore as "veg en oorlog", asook metafore van "sosiale organisasie". 
taal" (Giliomee, 2005), "ons word van alle kante beleër" (De Klerk, 2007:6) en "ons moet ons taal beskerm" (Peters, 2006:6; Du Toit, 2006:2). Sodoende word "die ander" gedemoniseer. Uit 'n morele oogpunt is dit interessant dat die NAP afwysend staan teenoor 'n "onnodige skuldgevoel oor die verlede".

Soos reeds in die inleiding tot hierdie artikel gesuggereer, reflekteer populêre Afrikaanse liedjies sommige van bogenoemde aspekte van identiteitsdiskoerse. As 'n besonder kragtige medium vir selfuiting mag musikale tekste as 'n ryk diskursiewe bron optree, aangesien die wyses waarop mense gekies het om hulle ervarings musikaal te dokumenteer, dieper insig in die ervaring van gebeure verskaf (Gilbert, 2005b:126). Gilbert (2005b:127) toon byvoorbeeld aan dat musiek op twee kenmerkende wyses as 'n interpretatiewe lens binne hierdie sosiale diversiteit funksioneer:

As an object (self-contained 'work' or song), it acts as a medium for the discussion and documentation of social disparity. As an activity, it was a place where that disparity was played out.

Liedjies as tekste is dus sowel 'n manier om 'n gegewe realiteit te beskryf as om aktief daaraan deel te neem (Gilbert, 2005b:134).

Met die oog op die verkenning van 'n seleksie van Afrikaanse vryheidsliedjies, word vanuit hierdie agtergrond oorgegaan na Steyn (2001) se beskrywing van "verhale van witheid" waarbinne wit postapartheidselfheid vergestalt word.13

\section{Vyf verhale van "witheid"}

Soos in die voorafgaande afdeling gesuggereer, impliseer die vloeibaarheid van identiteit dat Afrikanerskap nie as één essensialistiese volksidentiteit verstaan kan word nie. In postapartheid Suid-Afrika word die grense van Afrikaneridentiteit voortdurend heronderhandel en, soos Wasserman (2002) dit stel, huldig alle lede van 'n bepaalde "volks"-groep nie identiese veronderstellings en menings nie. Viljoen (2005:69) redeneer byvoorbeeld dat

[v]anuit die perspektief dat identiteit gekonstrueer word na aanleiding van die wyses waarop dit binne bepaalde diskoerse vergestalt word, ... geredeneer [sou] kon word dat tradisionele wit Afrikanerskap - soos trouens enige ander kulturele konstruk

13 Erkenning aan Martin Rossouw vir die uitlig van die relevansie van hierdie bron vir die huidige studie. 
- 'n 'fiksie' is waarbinne geskiedenis, ideologie en kulturele praktyke ineenvloei. Die samestelling van hierdie spesifieke identiteit berus gevolglik op geen onveranderlike, interne essensie nie, maar hang saam met konkrete sosiale verhoudinge en die materiële historiese en sosio-ekonomiese situering daarvan.

Dit is dus logies dat verskeie konstruksies van Afrikaneridentiteit in die nuwe Suid-Afrika sou ontstaan.

In Whiteness just isn't what it used to be beskryf Steyn (2001) vyf narratiewe wat deur wit Suid-Afrikaners gebruik word om sin te maak van die veranderende politieke en sosiale samelewing in SuidAfrika. ${ }^{14}$ Narratiewe ${ }^{15}$ dui in hierdie sin op samehangende sisteme van betekenis wat mense se begrip van realiteit vorm (Steyn, 2001: $x x x v i i i)$. Hierdie vloeibare raamwerk laat ' $n$ mens toe om verskillende, kompeterende realiteitsbeelde te skep deur middel van ' $n$ bepaalde repertorium van betekenis. Die verskillende weergawes of konstruksies van witheid is gelaai met teenstrydige belange, kompeterende magstrukture en ideologiese formasies. Die hoofideologiese diskoers tydens die apartheidsjare figureer binne hierdie vertellings as die "meesternarratief" (Steyn, 2001:xxxviii).

In terme van Steyn se "dominante apartheidsnarratief" is dit duidelik dat hierdie "meesternarratief" van witheid individue se materiële en psigologiese bestaan onderskryf en sodoende die dominante raamwerk gevorm het waarvolgens daar sin van die Suid-Afrikaanse samelewing gedurende die apartheidsera gemaak is (Steyn, 2001:58). In sy ideologiese funksie het hierdie narratief ook die oorkoepelende identiteit van Afrikaners gedurende apartheid gevorm. Die vyf narratiewe van witheid wat deur Steyn (2001) geïdentifiseer word, reflekteer egter elkeen onderskeidelik 'n onderskrywing, of 'n afwyking van vorige "meesterweergawes" van witheid.

\subsection{Narratief 1: "Steeds koloniaal na al hierdie jare" (Still colonial after all these years)}

Die eerste narratief wat Steyn (2001:153) identifiseer, naamlik Steeds koloniaal na al hierdie jare, is die mees fundamentalistiese

14 Steyn (2001) se studie fokus nie slegs op Afrikaners nie, maar sluit hierdie groepering in.

15 John Thompson wys juis op die ideologiese funksies van sodanige narratiewe (vgl. ook Schoeman, 1997:17). 
en paternalistiese van die narratiewe wat sy beskryf, en is totaal uit voeling met die realiteite van die magsverandering in die nuwe SuidAfrika. Hierdie verhaal konstrueer witheid volgens 'n onveranderbare magsverhouding tussen wit en swart en berus op die veronderstelling dat die voormalige verhouding met "die ander" behou of teruggewen kan word. Daar is twee weergawes van hierdie narratief: "Die bittereinder-kolonialis" (The hardliner colonial), wat die verlies van die vorige orde bekla en duidelik spreek van die meesternarratief, en "Die altruïs" (The altruist), wat besef dat aanpassings genoodsaak word, maar nog steeds verdedigend staan teenoor vergange waardes en die belang van witheid, soos verkondig deur die meesternarratief (Steyn, 2001:64-67).

Weergawes van Narratief 1 is in talle populêre liedjies vergestalt, waarin daar nostalgies terugverlang word na 'n Suid-Afrika wat in wese nooit bestaan het nie: 'n land sonder misdaad of regstellende aksie, waarin almal Afrikaans praat (Bezuidenhoudt, 2005:8). Hanru Niemand se verwerking van die bekende volksliedjie, "Sarie Marais" is tekenend van hierdie droom: "O, bring my terug na daai ou, ou land / daar waar my Sarie woon / Waar Siembamba nog speel oor die radio / Daai land was so wonderlik skoon." (Niemand, 2007.)

Hierdie konstruk van die ou Suid-Afrika figureer ook in tradisioneelAfrikaanse "saamsingliedjies" en slagspreuke soos "100\% Boer" en "Praat Afrikaans of hou jou bek" op T-hemde, wat gewild is onder lede van gehore wat konserte afsluit met die sing van "Die Stem" (Marais, 2006:17). Liedjies soos "Lekker in Suid-Afrika" van Zak van Niekerk (2007) dui op lirieke wat heeltemal uit voeling is met die nuwe realiteite, terwyl "Eish! Part 1" van die bekende kommediant Leon Schuster (2006) spreek van die verlies van die "goeie ou dae". Ddisselblom se liedjie "Hoor ons roep" (Ddisselblom, 2001), Jaco se "Sing in Afrikaans" (Jaco, 2007), asook Adam Tas se, "My moeder is 'n taal" (Tas, 2006)16 besing ook Afrikanersimbole, en spesifiek die taal wat beskerm moet word.

Die musikale vergestalting van hierdie narratief word ook gekenmerk deur die aanwending van ou Afrikanersimbole sonder tekens van ironie (Bezuidenhout, 2007:11). 'n Voorbeeld hiervan is Pieter Smith (2002) se musiek wat op keurspele van ou Afrikaanse volksliedjies berus. Hierdie tipe liedjies is oorwegend sentimenteel, soos byvoor-

16 Hoewel hierdie musiek nie van hoogstaande gehalte is nie, betrek dit 'n groot groep binne die Afrikaanse gemeenskap, en is dit nodig om kortliks daarna te verwys. 
beeld Jacques de Coning se weergawe van "Die Stem" (De Coning, 2000).

\subsection{Narratief 2: "'n Witte verdien nie hierdie nie" (This shouldn't happen to a white person)}

Die vertellers van Narratief 2 is oorwegend verontwaardig en aggressief en blameer die regering daarvoor dat hulle praktyke gebaseer is op omgekeerde rassisme en viktimisasie (Steyn, 2001:78). Hierdie sentimente blyk duidelik in populêre liedjies soos Abel Kraamsaal se liedjie, "B.E.E." (Genoeg is Genoeg, 2007): "Ons moet hande vat en saamstaan / Teen daai B.E.E. / [...] Omgekeerde rassisme is aan die orde van die dag."

Hierdie narratief bied slegs twee opsies, naamlik om te veg vir die voortbestaan en behoud van jou regte, of te vlug deur middel van "selfballingskap", wat soms op emigrasie neerkom of figuurlik geskied aan die hand van 'n onttrekking uit die samelewingsforum (Steyn, 2001:79). Die vertellers van hierdie narratief verklein ook die impak van die verlede op "die ander" en glo dat die voordele wat blankes in die verlede gehad het, toegeskryf kan word aan hulle persoonlike vindingrykheid, vaardigheid en aanhouvermoë (Steyn, 2001:71). Hulle glo dat praktyke soos landhervorming en regstellende aksie "natuurlik" moet gebeur as 'n soort inspanninglose osmose (Steyn, 2001:76-77).

Binne hierdie narratief word liedjies gevind wat ironie in sinisme verander, en wat van misdaad, korrupsie, emigrasie en geweld spreek, asook die skynheiligheid van nuwe leiers (Bezuidenhout, 2005:8). Sommige van die musiek van Die Brixton Moord en Roof Orkes en die musiek van Fokofpolisiekar resorteer onder hierdie narratief (vgl. Marais, 2006:17). 'n Voorbeeld hiervan is ook Koos Kombuis se nuwe liedjie, "Die fokkol song" (Genoeg is Genoeg, 2007). Die lied is 'n toekomsprojeksie op die jaar 2010 en uiteindelik het ons 'n kans om "vir die wêreld te wys van ons vriendelike democracy". Maar niks werk nie, daar is nie petrol, diesel, krag, water, of grappies om voor te lag nie. Die misdaad is nog steeds daar, daar is gate in die pad en die werkers staak, "jy kan maar kla en kla / dit help niks / so fokken baie fokkol in Suid-Afrika".

Nog 'n voorbeeld is Andries Bezuidenhout se liedjie "Nero van der Merwe se lied" wat byna 'n tipe apokaliptiese toekomsvoorspelling is. Alles wat eens mooi was is verwoes; die stad Johannesburg brand, "dinge het lankal uitmekaar geval / aanvanklik nog stadig / later so snel / [...] maar die lewe gaan aan, selfs in die verval / 
tussen ruïnes en murasies, moet mense nog dwaal" (Bezuidenhout, 2003). Valiant Swart se "Die bom kom", is ook 'n apokaliptiese toekomsvoorspelling: "Moeder Aarde skeur middeldeur en almal vergaan" (Swart, 2001). Vergelyk ook Johannes Kerkorrel se liedjies, "Toekomsramp" en "Derdewêreld" (Kerkorrel, 1992), asook Die Skim se liedjie, "My dorp" (Die Skim, 2007).

Die oproep tot Afrikaners om op te staan en te veg teen alles wat verkeerd is, vind ook duidelike weerklank in Afrikaanse liedjies. Voorbeelde hiervan is sigbaar in die werk van musikante soos Abel Kraamsaal in sy liedjie, "Stormweer", waarin hy Afrikaners uitdaag om weer helde te wees (Kraamsaal, 2005), en in Piet Paraat se liedjie, "Toema Jacob Zuma", waarin hy sing: "Ek is moeg en ek's gatvol en ek's reg om te struggle.” (Paraat, 2007.)

Die tweede permutasie van hierdie narratief wat op "self-ballingskap" dui deur jouself uit 'n onstabiele samelewing te onttrek, word deur Christopher Ballentine (2004:124) beskryf as 'n tipe gemaskerde "identiteit-in-skuiling", of as 'n "voortvlugtende" identiteit. Hierdie tendens blyk onder meer in Amanda Strydom se musiek. In haar treffende lied, "My kamer", sing sy byvoorbeeld:

Ek het lankal immigreer na 'n kamer in my kop Vandaar hou ek versigtig die wêreld om my dop

Beskut my teen 'n wêreld waar ek ongemaklik leef Bevry my van bagasie en laat my rustig wees

Ek reis al meer na binne. (Strydom, 1998.)

Soortgelyk projekteer talle wit Afrikaanse liedjies die idee van 'n reis, of vlug; ongedefinieerd in roete en onbepaald in lengte, met meerduidige bestemmings (Ballentine, 2004:124-125). 'n Voorbeeld hiervan is Strydom se liedjie, "Whisky, water, weemoed", waarin sy die wens uitspreek om ongebonde te kan reis na 'n "bestemming onbekend / geen bagasie, verlede vir ewig verby / uit die land uit, ek is vry" (Strydom, 1998). Hierby sluit die lirieke van die Afrikaanse sanger Swart aan wat dikwels op rusteloosheid, ontworteling en die onbekende fokus. Sy narratiewe beeld dikwels verlies uit; ook die verlies aan identiteit (Viljoen, 2005:78), byvoorbeeld in "Waar dromers dwaal" (Swart, 2002), asook in "Weeskind van die weste" (Swart, 1996). In een van sy populêrste liedjies, "Die mystic boer" 
(Swart, 1996), word die idee van Afrikaneridentiteit as sodanig bevraagteken (Viljoen, 2005:78) aan die hand van 'n soektog of 'n reis na die "Mystic Boer".

\subsection{Narratief 3: "Moenie wit dink nie, dan's als reg" (Don't think white, then it's all right)}

Die vertellers van Narratief 3 aanvaar die feit dat "witheid" binne die nuwe Suid-Afrika gerelativeer is. Hierdie groep probeer aanvaar dat blankes deel moet word van die sogenaamde reënboognasie. Hulle is eweneens ontevrede oor kwellings soos regstellende aksie en hoë belasting, en veral wit mans voel geteiken (Steyn, 2001:84-85). 'n Musikale weergawe van hierdie narratief is byvoorbeeld Mallies le Roux se lied, "Auckland blues": "Ek is wit en manlik en Afrikaans / my naam is Jacobus du Toit Terreblance / ek is 46 en desperaat / want die oorlogsveterane het my plaas afgevat." (Le Roux, 2007.)

Die weergawe van hierdie narratief wat Steyn (2001:153) karakteriseer as "Ons kan iets uitwerk" (We can work something out), is positief oor die veranderings in die land en soek nuwe, praktiese maniere om te oorleef en ' $n$ wit invloed in die nuwe Suid-Afrika vol te hou. Sonder om hulle "witheid" te herdefinieer of te ontken, veronderstel hulle gelykheid tussen die rasse en die afskaffing van groepsdominansie (Steyn, 2001:94-97). Vraagstukke rondom persoonlike moraliteit, die aanvaarding van verantwoordelikheid en kwessies rondom "wit skuldgevoelens" begin in hierdie verhaal te voorskyn kom (Steyn, 2001:98).

Hierdie narratief reverbereer verder in liedjies waarin kunstenaars kritiek uitspreek omdat hulle nog moet boet vir die verlede waarvan hulle nie deel was nie. Die omstrede groep Fokofpolisiekar se lied, "Brand, Suid-Afrika", se lirieke spreek byvoorbeeld kritiek uit teen die mislukking van die staat en dat hulle geblameer word vir die "sondes" van vorige generasies (Fokofpolisiekar, 2006). In Klopjag se lied, "Nie langer", sing hulle dat hulle enigiets sal doen om aan te beweeg: "Ek weet ons was verkeerd / kan ons asseblief aanbeweeg, Meneer? / Want ek sal nie langer jammer sê nie / ek sal agter in die tou staan / ons reënboog op my mou dra." (Klopjag, 2005.) Selfs in Die Helde se lied, "Reënboognasie" (Genoeg is Genoeg, 2007), wat positiewe elemente bevat, lê kritiek op die regering steeds onder die oppervlak. 


\subsection{Narratief 4: "'n Witter skakering van wit" (A whiter shade of white)}

Hierdie vertellers glo dat hulle heeltemal nie-rassisties is (Steyn, 2001:101). Die narratief beskerm die onskuld van blankes en toon 'n lae bewussyn van persoonlike skuld (Steyn, 2001:113-114). Van die hoofpleidooie wat gebruik word om hierdie konstruksie van "witheid" te regverdig, is onder andere die pleidooi vir 'n oorkoepelende identiteit. Hierdie individue sien hulleself as "Suid-Afrikaners" of as "Afrikane" (Africans). 17 Sommige wit Suid-Afrikaners gebruik hierdie etikettering met integriteit om die herdefiniëring van Suid-Afrika binne die konteks van Afrika te beklemtoon, terwyl ander dit meer gebruik as 'n verklaring van hulle eie onbetwisbare regte as "Afrikaners in Afrika" (Steyn, 2001:102-103).

Binne populêre wit musiek word hierdie narratief vergestalt in liedjies waar die verband met Suid-Afrika/Afrika in die postapartheidera mities, tentatief of niebestaande is (vgl. ook Ballentine, 2004:112). Ballentine identifiseer vier verskillende tendense onder hierdie musikante, naamlik kunstenaars wat musikaal of verbaal sonder enige ware inhoud na Afrika verwys, waar dit 'n abstraksie bly, groepe vir wie Afrika die primitiewe, eksotiese en die trans voorstel, en hulle wat "primitiewe" instrumente soos panfluite en didjeridoo's gebruik (Ballentine, 2004:112-113).

Jak de Priester se lied, "Afrika", is 'n sprekende voorbeeld van hierdie mitiese verwysing na Afrika, waar daar geen ware inhoud of wisselwerking met Afrika is nie. Hy eindig die lied af met die woorde "Nkosi sikelel i'Afrika", maar in plaas van oortuigende hibridisering, voel die gebruik van die gebed geforseerd en oppervlakkig; dit is slegs 'n kosmetiese verwysing sonder enige klaarblyklike begrip vir die ware betekenis van die woorde (De Priester, 2003).

Sommige wit Suid-Afrikaners binne hierdie groepering maak ook daarop aanspraak dat ons almal aan die binnekant fundamenteel dieselfde is, om hulleself sodanig te bevry van die las van ras. Hierdie groep glo dat sosiale posisie die gevolg is van persoonlike eienskappe, eerder as die beperkings van ras. Op hierdie manier vermy hulle dan enige konfrontasie met materiële ekonomiese en sosiale

17 Steyn (2001:103) verduidelik dat die klem wat daarop gelê word om "van Afrika" te wees vanaf die vroegste tye in Afrikaneridentiteit belangrik was. Hierdie losmaking van Europese wortels impliseer 'n aanspraak op burgerskap van die land teenoor swart Afrikane se eis van vroeëre vestiging. 
verskille, sowel as gevoelens van skuld wat met bevoorregting saamgaan (Steyn, 2001:109). Omdat hulle hulself as vry van enige rassebewustheid sien, voel hulle geregtig op besware teen die nuwe orde op dieselfde "nie-rassige" grond (Steyn, 2001:110). Daar is ook diegene wat glo dat hulle deel is van 'n sisteem wat buite hulle beheer is en gevolglik hoef hulle geen persoonlike verantwoordelikheid te dra nie (Steyn, 2001:111-113). Van laasgenoemde is Blouklip se liedjie, "Klaar met rugby" (Genoeg is Genoeg, 2007), 'n voorbeeld: "Verwoerd se kinders / dis ek en jy / maar ek het nooit vir hom gestem nie / ja glo jy vir my?" Kunstenaars sê ook dat hulle nie langer skuldig gaan voel en jammer gaan sê nie, want die nuwe regering is net so skuldig aan menseregtemisbruike: "Hou op geld mors op naamsveranderings / daar is mense sonder huise, kinders sonder kos / Wie is nóú die sondebok?" (Klopjag, 2005: "Nie langer"). Vergelyk ook die liedjie "Willem" (Genoeg is Genoeg, 2007) van Die Kaalkop Waarheid: "Hoeveel keer gaan ek nog probeer om my onskuld te bewys / hoeveel keer geëtiketteer, ontken en verwyt."

In "Klaar met rugby" (Genoeg is Genoeg, 2007) sing Blouklip dat hy onskuldig is aan apartheid, maar ook nie sonder om die nuwe regering te verwyt nie: "Ons betaal belasting vir heropbou / maar wys my die huise wat hulle daarmee bou." Minder positief is Paraat se lied, "Toema Jacob Zoema": "Ek was skaars 'n paar jaar oud toe Mandela vrygelaat is / maar my hele lewe lank word ek gestraf vir die sondes van my vaders." (Paraat, 2007.)

\subsection{Narratief 5: "Onder Afrika se hemel, of wit, maar nie heeltemal nie" (Under African skies, or, white, but not quite)}

Die vertellers van Narratief 5 hou nie vas aan die bekende diskoerse van "witheid" nie, maar ontleen hulle verhaal aan ander kulturele "repertoires" om nuwe subjektiwiteite te skep waarmee vorige opvattings van wit identiteit aangevul of vervang word (Steyn, 2001:115). Hierdie narratief neem drie gestaltes aan. Die eerste weergawe, "Ek weet nie wat my as witte te doen staan nie" (I just do not know what to do, being white), getuig van die probleme wat ervaar word deur blankes wat die Afrikanisering van die land ondersteun, maar nie weet hoe om hulle persoonlike ruimte binne hierdie veranderings te onderhandel nie (Steyn, 2001:153). Hiervan is die Brixton Moord en Roof Orkes se liedjie, "Fortuinverteller" (2005), wat 'n soeke na identiteit voorstel, 'n goeie voorbeeld. Ook Die Skim se liedjie, "Mama Afrika", spreek van die tweestryd wat hierdie narratief kenmerk: 
Mama Afrika, jy het my hart gesteel.

Mama Afrika, jy het my kar gesteel.

Mama Afrika, ek skuld jou.

Maar jy het ook iets verskuldig aan my.

Mama Afrika, my geskiedenis lê in jou binnelande.

Maar hoekom moet jy my stad se naam verander.

Mama Afrika, jy gee my my identiteit.

Maar jy gooi 'n klip deur my karruit. (Die Skim, 2007.)

Die vertellers van die tweede weergawe, "Ek wil nie meer wit wees nie" (I don't want to be white anymore), identifiseer met diepe skuldgevoelens. Hulle hanteer hierdie gevoelens deur die toeëiening van swartheid, óf deur 'n lewe van boetedoening. Hierdie individue raak waarlik in die stryd van "die ander" betrokke (Steyn, 2001:124-127).

Wit skuldgevoelens manifesteer onder meer in Die Brixton Moord en Roof Orkes se lied, "Geraamtes in jou kas", waarin hulle sing van die misdade wat gepleeg is onder apartheid se vaandel: "Jy onthou die stof / van 'n township se strate / en die haat in die oë / aan die end van jou geweer / want jy weet, jy weet: die geraamtes in jou kas het begin kriewel." En dan ook van die skaamte wat hierdie herinnering by hulle oproep:

So trek jou hoed oor jou oë

Vir Sharpeville en vir Ventersdorp.

En swaai aan jou droom

Sodat jou skoene nooit nat word

Van die modder op die grond

Hier en daar vermeng met bloed.

(Die Brixton Moord en Roof Orkes, 2002.)

In Swart se lied "Die donker kom jou haal", is die ondertone van skuld nog donkerder: "die illusie van onskuld en vryheid maak jou mal / besef dis te laat / die donker kom jou haal" (Swart, 1999).

Afrikaanse sangers en groepe wat positief was oor die reënboognasie en die nuwe Suid-Afrika het op verskeie maniere geïdentifiseer met hierdie tipe bevrydende postapartheidsorde en het liedjies geskryf wat die nuwe begin verwelkom het (Phillips, 1993), die vryheid van Madiba gevier het (Kombuis, 1997b), en die hoop uitgespreek het dat die "reënboognasie sal aanhou skyn" (Goosen 
aangehaal in Ballentine, 2004:110). Strydom se lied, "Ek sal staan", is ook tekenend van hierdie blydskap:

Ek was lank in die woestyn

sonder water sonder wyn

maar ek het stadig teruggeloop

krom gebuk en afgestroop

my spore lê soos woorde in die sand

en soos Jona ingesluk

uitgespoeg en reggeruk

word ek wakker in 'n helder nuwe land. (Strydom, 2000.)

Tekenend van 'n breuk met die verlede, het musikante rassistiese terminologie omgekeer deur 'n blanke gehoor aan te spreek as "wit kaffirs van Afrika" (Goosen, 1996; Kombuis, 1997a). Plaaslike swart tale is by Afrikaanse tekste gebruik, soos "Ndiyakholelwa/Ek glo" (Strydom, 2003), "Izinyanya/Die vergetenis" (Strydom, 2003), asook Goosen se liedjie, "Moya" (Goosen, 1993). Soortgelyk dui Goosen se liedjie, "Cri-de Coeur" (Goosen, 1998), op 'n vermenging van kulture, deurdat die liedjie eindig met 'n verwerking van "Die Stem" en "Nkosi sikelel i'Afrika".18 Swart musici is ook in uitvoerings ingesluit (Kerkorrel, 1992; Rauch, 1995) en kunstenaars soos Kombuis (2000) maak gebruik van 'n "kleurlingdialek" (Ballentine, 2004:109112).

Die aanvanklike euforie oor die reënboognasie het egter gou plek gemaak vir sinisme en ontnugtering oor die nuwe regering se onbevoegdheid om misdaad, korrupsie en armoede te beveg. Skielik het kunstenaars besef dat die reënboognasie nie net maanskyn en rose is nie en het hulle nie meer geweet hoe om hulleself te definieer nie.

Populêre kunstenaars het weereens op protestemas begin fokus, ${ }^{19}$ soos in Kerkorrel se lied, "Sê-sê", waarin hy "die vet sotte op die rooi tapyt" blameer en identifiseer met diegene wat onder die nuwe bestel ly (Kerkorrel, 1996). In "Die stad bloei vanaand" (Kerkorrel,

18 Ook reeds tydens apartheid was daar sulke elemente sigbaar, soos in die liedjie "Afrika" (1980) deur Anton Goosen waar hy die "ander" verbind deur middel van "Nkosi sikelel i'Afrika" aan Afrikaner-identiteit: "Nkosi sikelel i'Afrika / die ver paaie neem my terug die blou berge oor / terug op die spoor van die kakebeenwa / waar die hemel swaar aan al sy sterre dra." 
2000), verwys hy metafories na die droom van die nuwe Suid-Afrika wat gesteel is: "alles wat mooi was, het tot as verbrand" (vgl. Ballentine, 2004:117). Soortgelyk sing Kombuis oor die korrupsie en geweld van die nuwe regering en die siniese vermyding van aanspreeklikheid in sy liedjie, "Blameer dit op apartheid" (Kombuis, 1997a).

Meer radikale elemente het ook binne populêre musiekvorms neerslag gevind. Die Afrikaanse groep, Battery 9, wat hoofsaaklik in 'n tipe "industriële dansgenre" werk (Ballentine, 2004:119), sluit op hulle album, Wrok, 'n snit, "Blaas hom", in waarin die Afrikaanse sanger rap oor sy woede omdat hy nogmaals besteel is en oor die wraak wat hy op die twee rowers gaan neem (Battery 9, 1998). Ook Strydom sing oor haar woede in "Doekvoet": "Kill the settler kill the boer / breek die skole af / hit the woman rape the child / niemand word gestraf." (Strydom, 2003.) Gian Groen sing oor die leefwêreld van "die ander", misdaad en armoede in sy liedjie, "Mitchells Plain", en hy sluit die koorgedeelte treffend af met: "Vir jou African dream, meneer / sal ons hopeful sit en wag." (Groen, 2002.) Vergelyk ook Glaskas se liedjie, "Vrede" (Genoeg is Genoeg, 2007): "Waar is die sogenaamde Afrika-Renaissance / Skrik jou dood as jy wakker skrik van hierdie droom / Daar skyn 'n derde wêreldoorlog in hierdie tweede kans."

Die laaste weergawe van hierdie narratief, "Hibridisering - die manier om te gaan", (Hybridisation - that's the name of the game), word vertel deur die sogenaamde "wit Afrikane".20 Deur swartheid met witheid te inkorporeer, dekonstrueer hulle "witheid" en maak die dinamika wat oorspronklik die meesternarratief gekonstrueer het, ongedaan (Steyn, 2001:153). Hierdie vertellers toon 'n akute begrip vir witheid as ' $n$ sosiale posisie geassosieer met voorregte en toon empatie vir hoe dit "die ander" beïnvloed het (Steyn, 2001:128). Hulle verwys ook nie na die posisie van blankes as gemarginaliseerd nie en die verlies van dominansie is nie gelykstaande aan 'n persoonlike nederlaag nie, maar wel die einde van witheid soos die meesternarratief dit vertel het (Steyn, 2001:142). Die narratief vermy nie persoonlike implikasie in die sosiale proses van integrasie nie (Steyn, 2001:115).

Tekenend van musikaal-gehibridiseerde identiteite is byvoorbeeld Strydom se lied, "Strydom/Amandla" (Strydom, 1996), waar sy haar

Nie altyd 'n positiewe konsep nie (vgl. Narratief 4). 
identiteit met 'n Afrika-vryheidskreet verbind. Terselfdertyd is daar ook 'n gewaarwording dat die meesternarratief alles skeefgetrek het, soos byvoorbeeld in Strydom se, "Kom tog by die punt uit", waar sy kritiek op die ou orde uitspreek: "Ons het nie die Bybel reg verstaan." (Strydom, 1998.)

Sommige liedjietekste suggereer dat nugteres onder die nuwe wit Suid-Afrikaners besef dat die land nog 'n ver pad het om te loop. 'n Goeie voorbeeld hiervan is Strydom se, "Sondag in Soweto", waarin sy sing: "My velkleur is die uniform van die ou orde / en vryheid en gelykheid het 'n wet geword / maar hier sien jy nog die spore van die blinde haat / die tye het verander, vir sommiges te laat." (Strydom, 2003.) In Die Melktertkommissie se liedjie, "A song", kom hierdie insig meer optimisties na vore: "A long walk to freedom het meer pitstops as wat tyd maybe toelaat / maar thula my baby / jou pas het lankal verbrand / maar jou passie bly die brandmerk / en die wonderwerk van ons land." Die refrein van hierdie liedjie is ook sprekend van hibridisasie, deurdat die Afrikaanse kultuur en dié van "die ander" hier aan mekaar verbind word.

Betaal jy lobola met beeste of geld?

En is Shaka en Ragel albei jou helde?

Wonder jy oor die kleur van jou taal?

Maybe het apartheid al lankal verdwaal.

(Die Melktertkommissie, 2006.)

Sommige kunstenaars fokus ook op identiteit as iets wat nie meer 'n gegewe is nie. Deur hibridisasie en die soeke na 'n nuwe, meer inklusiewe identiteit, word besef dat identiteit nie meer vas staan nie. Vergelyk Swart se liedjie, "Deur die donker vallei", waar hy 'n metaforiese, vreemde land skep waarin identiteit nie langer 'n gegewe is nie: "Gaan vra die mense in die strate / waar kom jou nuwe naam vandaan." Hy is ook meer sober in sy beskrywing van wit skuldgevoelens: "Vanaand staan ek met leë hande / en sing van onskuld en van blaam." (Swart, 1999.)

\section{4. 'n Ideologies-kritiese perspektief}

Deur bogenoemde narratiewe te ontleed aan die hand van metafooranalise en ideologiekritiek, kan nou 'n duideliker blik gewerp word op denkpatrone onderliggend aan Afrikaanse vryheidsliedjies. Dirven (1994:179) redeneer dat 'n metafoorbenadering tot ideologie 'n ryke potensiaal besit om ideologiese aspekte van sosiale praktyke en diskoerse bloot te lê. Deur metafore uit te lig wat sodanige praktyke of diskoerse diepliggend ten gronde lê, word dit moontlik om 
ideologieë waar te neem wat andersins nie maklik ontmasker sou kon word nie. In hierdie opsig glo Thompson (1990:278) dat figuratiewe aspekte, soos verskuil binne kulturele diskoerse, as "a realm of power and conflict in which 'meaning' may be a mask for repression" mag funksioneer. Binne hierdie konteks mag die metafoor idees en waardes projekteer wat op materieelspesifieke wyses geproduseer en verbruik word en daarom ten nouste met die uitoefening van ongebalanseerde magsverhoudings verbind kan wees.

In terme van die onderwerp van hierdie artikel en binne die konteks van Visagie (1996) se denke, sou die metaforiese inhoud van liedjies 'n ideologiese agenda as sodanig byvoorbeeld op twee maniere kon dien. Eerstens, deur die versterking van dominasieverhoudings tussen sosiale groepe, en tweedens, deur die representasie van 'n vorm van estetiese mag wat oorheersend in die lewens van individue of gemeenskappe word, en sodoende tot 'n eensydige, hipernormatiewe lewensuitkyk lei wat alle ander waardes of norme onderdruk, ignoreer of herinterpreteer - met 'n mate van distorsie van die norm se argumenteerbare, unieke inhoud.

Een van Visagie se modelle, naamlik sy denke rondom 'n reeks argetipiese figure of "posture", mag 'n nuttige hulpmiddel wees om die metaforiese inhoud van vryheidsliedjies te ontmasker. Visagie (1990:10 e.v.) wys daarop dat argetipiese figure, verteenwoordigend van fundamentele temas onderliggend aan die menslike bestaan, binne tekste en diskoerse as sogenaamde "wortelmetafore" mag optree wat die toegang tot ideologiese inhoud moontlik maak. Hy identifiseer 'n spektrum van sodanige figure wat 'n verskeidenheid "posture" verteenwoordig en wat verband hou met fundamentele gebeure, tipies van menslike ervaring, soos die vegter, reisiger, werker, minnaar, speler, ensovoorts (Visagie, 1990:10 e.v.). Rondom hierdie spektrum argetipiese wortelmetafore identifiseer hy verder twee omsirkelende metafore van universele en besonder diep eksistensiële belang, naamlik die antitetiese metafoorgroeperings van behou/verloor/vind en staan/val/opstaan. Hierdie metafore tree op uitsonderlike wyse na vore by die uitdrukking van die diepste menslike ervarings (Visagie, 2008).

In terme van die analise van die liedjies wat in hierdie artikel bespreek word, verskaf die studie van argetipiese figure 'n onontbeerlike model vir morele oorweging en nadenke waarin die vraag verwant is, nie net aan die teoretiese relevansie nie, maar ook aan die betekenis van die menslike bestaan (vgl. ook Viljoen, 2002:2). Hoewel verteenwoordigend van alledaagse gebeure in die lewens van mense, mag Visagie se posture dus gesien word as eksistensiële 
aksies wat die herhalende patrone van die menslike situasie simboliseer en dus as "wortelmetafore" funksioneer (Visagie, 1990:10 e.v.; sien ook Viljoen, 2002:2).

Binne die seleksie van liedjies soos hierbo aangebied, is daar sekere metafore wat onomwonde na vore tree. Narratief 1 getuig byvoorbeeld sterk van die verlies wat Afrikaners voel. Dit kan onder meer gesien word in die nostalgiese terugverlang na die "goeie ou dae" (Schuster, 2006; Niemand, 2007) en in negatiewe verwysings na die toekoms (Bezuidenhout, 2003; Swart, 2001). Lirieke is oorwegend sentimenteel (De Coning, 2000; Jaco, 2006; Tas, 2006) en daar word van tradisies en trots vir die vaderland en die taal gesing. Verwysings na "moeder" (Tas, 2006) en "my skouers sal jou dra" (Jaco, 2006) toon dat kunstenaars voel hulle moet vir die Afrikaanse taal en kultuur "sorg".

Liedjies verteenwoordigend van Narratief 2 is ryk aan stryd- en vegmetafore ("opstaan teen die monster" (Liesl, 2007:5); "ons het die reg om te veg" (Snotkop, 2005); "moeg en gatvol en reg om te struggle" (Paraat, 2007), ens.). Mense word aangemoedig om weer helde te wees (Kraamsaal, 2005; Die Helde, 2007) en te veg teen dít wat verkeerd is, ook teen die idee dat die taal "verkrag" word (Kraamsaal, 2005).

Newens die metafoor van die vegter staan dié van die reisiger as 'n meganisme om aan die sosiale en ekonomiese omstandighede in Suid-Afrika te ontsnap. Talle Afrikaanse vryheidsliedjies projekteer die idee van 'n reis of 'n vlug - ongedefinieerd in roete en onbepaald in tyd - die wens om ongebonde en sonder enige bagasie te kan reis (Strydom, 1998). Hierdie ontvlugting kan ook verwys na versteekte identiteite, waar mense hulle uit die samelewingsforum onttrek (Strydom, 1998; Die Skim, 2007). Hiermee saam hang die metafoor van die swerwer, sonder 'n tuiste, sprekend van rusteloosheid, ontworteling en die onbekende (Swart, 1996; 2002; Die Skim, 2007).

Liedere wat by Narratief 3 aansluit, stel die metafoor van die werker voor. Hulle is betrokke by die projek van nasiebou en is bereid om saam te werk, solank hulle minderheidsregte wel beskerm word en daar nog 'n plek vir hulle is en vir die uitleef van hulle talente (Die Skim, 2007; Die Helde, 2007).

Die liedjies wat by Narratief 4 inskakel, beklemtoon onskuld en slagofferskap (Die Kaalkop Waarheid, 2007; Kraamsaal, 2007). Tiperings as Afrikane (Africans) dui ook op die poging om onskuld te 
probeer bewys: "hoekom moet ek nog skuldig voel as ons altwee 'van Afrika' is" (vgl. De Priester, 2003), terwyl ander lirieke verantwoordelikheid vir apartheid ontken (Paraat, 2007; Blouklip, 2007). Hier kan 'n mens na die oorwegende metafoor verwys as 'n tipe alternatiewe of "verdraaide" reisiger. Verwysings na slagofferskap en marginalisasie dui op onttrekking uit 'n samelewing waarin mense geteiken voel as gevolg van witheid en Afrikanerskap. Vandaar ook die woede omdat hulle steeds verantwoordelik gehou word vir die "sondes van hulle vaders" (Fokofpolisiekar, 2006).

Die vertellers van Narratief 5 identifiseer met gevoelens van skuld (Brixton Moord en Roof Orkes, 2005; Swart, 1999). Identiteit is ook nie meer 'n gegewe nie (Swart, 1999). Hoewel daar talle voorbeelde van positiewe integrasie en hibridisasie is (Groen, 2002; Strydom, 2003), verwys die meeste populêre Afrikaanse kunstenaars, wat aanvanklik gejubel het oor die rëenboogeuforie (Kombuis, 1997b; 2000; Strydom, 2003; Goosen, 1996; 1998; Kerkorrel, 1992), iewers in hul post-1994 oeuvre na gevoelens van moedeloosheid, woede en ontnugtering as gevolg van korrupsie in die regering, misdaad, ensovoorts (Groen, 2002; Kombuis, 1997a; 2007; 2008; Strydom, 2003).

Uit die bostaande oorsig is dit duidelik dat al die narratiewe, soos in die huidige seleksie van liedjies vergestalt is, tot ' $n$ mindere of meerdere mate metafore van verlies projekteer; die verlies van die goeie ou dae, die verlies van tuiste en bestaansreg, ensovoorts. Individue het die droom van die nuwe Suid-Afrika waarin almal saam in vrede bly, verloor en hulle voel ontnugter en moedeloos. Dit is interessant dat in reaksie hierop, verskeie kunstenaars die relevansie van die Afrikaner binne die nuwe Suid-Afrika probeer herbevestig. Rian Malan (2005) verwys byvoorbeeld metafories na "wortels" wat "diep" in hierdie aarde "geplant" is in sy liedjie "Alien, inboorling". 'n Neerslag van dieselfde tipe sentimente word ook gevind in liedjies soos Johan Groenewald (s.a.) se lied, "In Afrika", en Die Skim (2007) se, "Mama Afrika".

Ook die versteekte meesternarratief kom duidelik in die bogemelde metafore tot uiting. In terme van resente verskuiwings binne die Suid-Afrikaanse samelewing, kan dus gekonstateer word dat die apartheidsmeesternarratief, hoe gefragmenteerd ook al, waarskynlik nog vir 'n geruime tydperk deel sal bly van die politieke onderbewuste in Suid-Afrika. Steyn (2001:154) bevind inderdaad dat al die narratiewe, ook dié wat witheid herdefinieer, hierdie narratief in die een of ander vorm oproep. Anderson (1990:25, 27) verduidelik dit soos volg: 
[T] disappear - people simply inhabit them in a different fashion [...] people [are] find[ing] it possible to retain some sense of their connection to older traditions and at the same time to create new arrangements.

Soos deurgaans in hierdie artikel beklemtoon is, is die nuwe SuidAfrikaanse samelewing tekenend van 'n komplekse verskeidenheid weergawes van wit identiteit. Van die narratiewe wat Steyn (2001) uitlig kom tegelykertyd in sommige liedjies voor, terwyl ervarings van selfheid ook dikwels op meer as een narratief berus. Gevolglik kan gekonstateer word dat die ideologiese inhoud van sowel die lirieke as die musiek van Afrikaanse vryheidsliedjies op komplekse wyse ineen en uitmekaar vloei.

Die bespreking hierbo maak dit daarom juis duidelik dat daar in eietydse Afrikaanse vryheidsliedjies geen sprake is van één vooropgestelde idee van Afrikanerwees nie. Alexander (aangehaal in Scholtz, 2004) waarsku juis teen die strewe om 'n nuwe identiteit vir al die Afrikaanssprekers te probeer skep, 'n nie-bestaande sosiale identiteit, wat "gedwonge, kunsmatig en pre-[ge]fabriseerd" sal voorkom. Dit sou juis ideologies wees om voor te gee dat daar van "die Afrikaner" gepraat kan word. Dat identiteit, 'n persoon se "ek", uitsluitlik deur kulturele affiliasies bepaal sou word, is uiteraard 'n ideologiese vorm van kulturalisme; dus is dit nodig om te onderskei tussen die persoonlike en kulturele identiteit van 'n individu, alhoewel eersgenoemde altyd laasgenoemde transendeer. Dit is dikwels strategieë van taalaktiviste dat hulle namens die Afrikaner praat (Visagie, 2008). 21

Hierdie waarneming bring ' $n$ mens terug tot by die sogenaamde "Neo-Afrikaanse Protesbeweging" of NAP, waarvan daar in die inleidende dele tot hierdie artikel melding gemaak is. Daar is genoem dat hierdie groep identiteitsvraagstukke by wyse van 'n magsdiskoers aanraak, wat hoofsaaklik tot die regering gerig word en wat hoofsaaklik op kwessies van taal en kultuur fokus. As verteenwoordigend van Narratief 3 en tot 'n mindere mate Narratief 4, gebruik hierdie beweging taal as 'n eufemisme vir ras, om sodoende hulle stryd teen integrasie te kamoefleer en op hierdie manier word rassisme, weliswaar op 'n bedekte wyse aan die ou idee van die volksideologie gekoppel.

21 Dieselfde strategie kom egter ook by anti-Afrikanergroepe of in antiAfrikanerdiskoerse voor. 
Dit is ironies dat 'n hipernormatiewe "volksmondweergawe" van hierdie diskoers vergestalting gekry het in Bok van Blerk se liedjie, "De la Rey" (Van Blerk, 2006). In die eerste plek word Generaal De la Rey, 'n leiersfiguur uit die Afrikaner se verlede, opnuut opgeroep as 'n volksleier en held wat opgestaan het teenoor die sinnelose noodlot van "die Boer". Du Preez (2006) skryf dat "die eksistensiële krisis vir eens opsygeskuif is ter wille van 'n heroïese, dog nostalgiese opstelling van identiteit". Tweedens roep die woorde, "Maar die hart van 'n boer / lê dieper en wyer hulle gaan dit nog sien / My huis en my plaas / tot kole verbrand", beelde op van 'n identiteit wat geaard is in 'n sterk verbintenis met plek. Dit word herbevestig in die musiekvideo deur die toneel van 'n boer wat hurkend 'n handvol grond opskep. Du Preez (2006) skryf dat die verbintenis tussen plek en identiteit trouens só sterk is dat dit "vlamme en vuur diep binne" die verteller oproep; "identiteit is hier nie onbekend nie, maar iets waarop gestaan kan word, iets waarvoor opgestaan kan word" (Du Preez, 2006).

Die metafore van die vegter en die held word duidelik in die lied geskets. "Die volk" word ook uitgebeeld as slagoffers van die Britse verskroeideaarde-praktyk en die konsentrasiekampe. Dit is egter 'n trotse volk, "'n nasie wat weer op sal staan", 'n volk wat aan SuidAfrika behoort. Die musikale inkleding berus op triomfantlike oorwinningsmusiek met die mars en snaartrom as bekende "oorlogsclichés". Hoewel Van Blerk by herhaalde geleenthede gesê het dat die lied geen politieke agenda dien nie, het mediamateriaal getoon dat die lied baie jongmense tot trane geroer het, terwyl hulle hand op die bors saamsing (Versluis, 2007:3); en dit terwyl hulle ten minste drie generasies van die konsentrasiekampe verwyder is en ook nie deel gehad het aan "die goeie ou dae" nie.

Op watter wyse dra hierdie waarnemings by tot 'n dieper insig met betrekking tot die identiteitsdiskoerse tans in ons land? Die Britse populêre musikoloog Simon Frith (1996:110) glo dat musiek 'n besonder insiggewende bron is in die bestudering van identiteit. Hy voer aan dat musiek, net soos identiteit, sowel 'n uitvoering as 'n storie is; vertellings wat lig werp op "the social in the individual and the individual in the social" (Frith, 1996:110). Binne Visagie (1994) se kritiese raamwerk is daar in hierdie artikel geïmpliseer dat hierdie "wisselwerkende" tipe identiteitskonstruksie egter nie noodwendig net "goedaardig" kan wees nie, maar dat ideologiese konsepsies die ervaring van identiteit deur middel van musiek, selfs deur die suiwer estetiese aspek daarvan, kan infiltreer. 
Hou hierdie waarneming maar net nog 'n manifestasie van pessimisme in? Word hierdie negatiewe ondertoon maar slegs keer op keer deur "wortelmetafore" van verlies onderstreep, soos aangetref in 'n wye seleksie van musikale verhale soos hierbo aangebied? Dui die metaforiese inhoud van liedjies binne hierdie konteks op die gevare van 'n gefragmenteerde samelewing waarin kulture van minderheidsgroepe en etniese verskille aan die een kant "gevier" word, maar aan die ander kant mag lei tot fundamentalisme (vgl. Steyn, 2001:152)?

Steyn (2001:170) voer aan dat blanke Suid-Afrikaners tans 'n baie belangrike rol in ons land kan speel indien hulle die identiteit van die "postkoloniale ruimte" betree. Wat nodig is, glo sy, is 'n sekere mate van hibridisasie en dat al hoe meer wit Suid-Afrikaners stelselmatig nader aan hierdie narratief moet beweeg (Steyn, 2001:168). Hibridisasie beteken egter nie dat Afrikaners hulle plek in die land moet prysgee nie. Dit dui eerder op die potensiaal vir nuwe opwindende maniere van syn, sowel as die moontlikheid van 'n meer stabiele, gegronde identiteit wat vorentoe na 'n toekoms in Afrika kyk (Steyn, 2001:146). Slegs deur die dekonstruksie van ideologiese witheid en die skep van heterogene identiteite, kan blankes hiervolgens volkome deel word van die nuwe Suid-Afrika. Dit behels, onder andere, die erkenning van vrese en skuld en om te leer om ernstig met die leefwêreld van "die ander" om te gaan, asook die opneem van die verantwoordelikheid vir die ontwikkeling van 'n nuwe subjektiwiteit (Steyn, 2001:141).

Ten slotte kan opgemerk word dat argetipes op 'n meer basiese of dieper vlak van die onderbewuste funksioneer as byvoorbeeld die verdedigingsmeganismes van ander psigodinamiese patrone. Dit verteenwoordig oorgeërfde, intrinsieke tendense in kognisie, beeldvorming en menslike emosie. Blatner (2004) voer aan dat argetipes "verlengings" is van instink soos uitgedruk in menslike ervaring, en as sodanig word manifestasies daarvan nie alleen in kuns, rituele en drome aangetref nie, maar ook in ingeburgerde volksgewoontes. Die oorheersende aanwesigheid van die wortelmetafore en argetipiese "postuur" van verlies, soos aangetref in die seleksie van Afrikaanse vryheidsliedjies wat in hierdie artikel bespreek is, illustreer moontlik ten diepste dat die proses wat Steyn (2001:170) beskryf, fundamenteel beteken dat wit Afrikaners "tot 'n ander besef van hulle plek in die geskiedenis sal moet kom". Die situasie van Afrikanerwees in die nuwe Suid-Afrika is baie meer kompleks as wat selfs hierdie studie aantoon, deurdat die meeste Afrikaners gekonfronteer word en deelneem aan sekere aspekte van die meesternarratief, maar ook 
afwyk en afkeurend daarteenoor staan. Moontlik is die enigste verantwoorde spekulasie in hierdie verband die uitspraak dat slegs die geslagte wat kom sal bepaal of hierdie nuwe besef in die teken van verlies of van behoud sal staan.

\section{Geraadpleegde bronne}

ALBERTINI, B., LEE, B., MILLNER, M., PAVILLE, K., RUTKOWSKI, A. \& WAGNER, B. 2000. Introduction: is there life after identity politics? New literary history, 31(4):621-626.

ALLEN, L. 2005. Circuits of recognition and desire in the evolution of black South African popular music: the career of the penny whistle. SAMUS, 25:31-51.

ANDERSON, W.T. 1990. Reality isn't what it used to be. San Francisco: Harper \& Row.

ANON. 2001. Dit wil lyk asof intellektuele wat steeds. Die Burger: 11, $31 \mathrm{Mrt}$.

ASANTE, M.K. \& MAZAMA, A. 2005. Encyclopedia of black studies. London: MacMillan.

BALLENTINE, C. 2004. Re-thinking "whiteness"? Identity, change and "white" popular music in post-apartheid in South Africa. Popular music, 23(2):105131.

BEZUIDENHOUT, A. 2005. Is die musiek 'n trein wat ontspoor? Rapport: 8, 23 Okt.

BEZUIDENHOUT, A. 2007. From Voëlvry to De la Rey: popular music, Afrikaner nationalism and lost irony. http://www.litnet.co.za/cgi-bin/giga.cgi? $\mathrm{cmd}=$ cause_dir_news_item\&news_id $=11123$ \&cause_id $=1270$ Date of access: 13 S̄ept. 2007.

BLATNER, A. 2004. The relevance of the concept of "archetype". http://www.blatner.com/adam/level2/archetype.htm Date of access: 24 May 2008.

DE KLERK, S. 2007. Laat die liedjies inrol. Volksblad: 6, 27 Feb. 2007.

DIRVEN, R. 1994. Metaphor and nation, metaphors Afrikaners live by; Duisburger arbeiten zur Sprach- und Kulturwissenschaft. Duisburg papers on research in language and culture. Bd. 22:152-180.

DU PREEZ, A. 2006. Van generaals en kapteins: kaptein, kaptein waarheen ry die trein? Die vrye Afrikaan. http://www.vryeafrikaan.co.za/site/index.htm Datum van gebruik: 5 Feb. 2007.

DU TOIT, Z.B. 2006. Nuwe name vir nuwe Afrikaner-groepe. Rapport (Perspektief): 2, 26 Mrt. 2006.

FITZPATRICK, M. 2007. De la Rey bring volkstrots terug vir geslag X. Volksblad: 1, 28 Feb. 2007.

FRITH, S. 1996. Music and identity. (In Hall, S. \& Du Gay, P., eds. Questions of cultural identity. London: Sage. p. 108-128.)

GELBER, L. 1982. Encyclopedie van het levende Vlaamse volkslied (twee dele). Sint-Martens: Latem.

GILBERT, S. 2005a. Popular song, gender equality and the anti-apartheid struggle. (In Walton, C. \& Muller, S. eds. Gender and sexuality in South African music. Stellenbosch: Sun e-press. p. 11-19.) 
GILBERT, S. 2005b. Music as historical source: social history and musical texts. International review of the aesthetics and sociology of music, 36(1):117-134.

GILIOMEE, H. 2003. The Afrikaners, biography of a people. Kaapstad: Tafelberg.

GILIOMEE, H. 2005. Die post-nasionale Afrikaner: ondermynende en opbouende gedagtes. Toespraak by gala-aand van die FAK, Die SuidAfrikaanse Akademie vir Wetenskap en Kuns. http://www.akademie.co.za/ toesprake_die_postnasionale_afrikaner.htm Datum van gebruik: $28 \mathrm{Mei}$ 2007.

HALL, S. 1996. Introduction: who needs "identity"? (In Hall, S. \& Du Gay, P., eds. Questions of cultural identity. London: Sage. p. 1-17.)

MARAIS, D. 2006. Is Afrikaners dan net plesierig? Beeld: 17, 5 Mei.

MULLER, S. 2001. Exploring the aesthetics of reconciliation: rugby and the South African National Anthem. South African journal of musicology, 21:19-38.

OLIVIER, B. 2006. Die kompleksiteit van identiteit in demokrasie: Lacan. Tydskrif vir geesteswetenskappe, 46(4):482-497.

PETERS, M. 2006. Oorsig en repliek: voorwaardes vir vryheid. http://www. dieafrikaner.co.za/rubrieke.htm Datum van gebruik: 26 Feb. 2007.

PYPER, B. 2005. To hell with home and shame! Jazz, gender and sexuality in the Drum journalism of Todd Matshikiza, 1951-1957. (In Walton, C. \& Muller, S., eds. Gender and sexuality in South African music. Stellenbosch: Sun Press. p. 19-27.)

ROBERTSON, M. 2004. Imagining ourselves: South African music as a vehicle for negotiating white South African identity. Journal of the musical arts in Africa, 1:128-137.

ROODT, J. 2006. Jy het 'n eie De la Rey in jou. Beeld: 18, 25 Des.

SCHOEMAN, P.G. 1997. Ideology, culture and education. Bloemfontein: Tekskor.

SCHOLTZ, L. 2004. Kan gedeelde identiteit vir wit/bruin ontwikkel? Die Burger: 18, 3 Sept.

STEYN, M. 2001. Whiteness just isn't what it used to be: white identity in a changing South Africa. New York: University of New York Press.

THOMPSON, J. 1990. Ideology and modern culture: critical social theory in the era of mass communication. Cambridge: Polity.

VAN DER MERWE, A.S.P. 2003. Postkolonialiteit in die twintigste- en een-entwintigste-eeuse Afrikaanse drama met klem op die na-sestigers. Pretoria: Unisa. (Ongepubliseerde Ph.D.-proefskrif.)

VAN DER MERWE, J.C. 2008. Onderhoud met outeur. Bloemfontein. (Onderhoud gevoer op 20 Mrt. 2008.)

VERSLUIS, J.M. 2007. Kind sing in trane saam aan Bok se voete. Volksblad: 3, 26 Feb.

VILJOEN, M. 2002. Ideologically compromised discourse between Ghetto and Desert: gospel rap and ideology: exploring new paths in critical musicology. Bloemfontein: Universiteit van die Vrystaat. (Ongepubliseerde proefskrif.)

VILJOEN, M. 2005. Johannes Kerkorrel en post-apartheid Afrikaner identiteit. Literator, 26(3):65-81. 
VISAGIE, P.J. 1990. The sub-theories of archaeological discourse analysis: Theory 1: Developing a semiological hermeneutics for archival discourse. Bloemfontein: Universiteit of the Free State. (Unpublished M.A. dissertation.)

VISAGIE, P.J. 1994. The name of the game in ideology theory. Bloemfontein: Universiteit of the Free State. (Unpublished M.A. dissertation.)

VISAGIE, P.J. 1996. Power, meaning and culture: John Thompson's depth hermeneutics and the ideological topography of modernity. South African journal of philosophy, 15(2):73-83.

VISAGIE, P.J. 2008. Onderhoud met outeur. Bloemfontein. (Onderhoud gevoer op 20 Mrt. 2008.)

WASSERMAN, H. 2002. Waardevolle nuwe reeks oor SA identiteite. Beeld: 9, $11 \mathrm{Mrt}$.

\section{Diskografie}

BATTERY 9. 1998. Wrok. Ticticbang. (BANGCD 038.) [CD].

BEZUIDENHOUT, A. 2003. Insomniak se droomalmanak. SAMRO. (RR 043.) [CD].

BLOUKLIP. 2007. Klaar met rugby. Op: Genoeg is genoeg, kompilasie. Hoezit. (HOEZD165.) [CD].

BRIXTON MOORD EN ROOF ORKES. 2002. Spergebied. Rhythm. (RR 021.) [CD].

BRIXTON MOORD EN ROOF ORKES. 2005. Terug in skubbe. Rhythm. (RR 057.) [CD].

DDISSELBLOM. 2001. Bang. Reneswha. (ddblom1.) [CD].

DE CONING, J. 2000. Girl van die klein Karoo. Sonopress, Select Musiek. (SELBCD 451.) [CD].

DE PRIESTER, J. 2003. Sally Williams nougat. Rhythm. (JDP 001.) [CD].

DIE HELDE. 2007. 'n Eeue-oue melodie. DPK. (DPK 004.) [CD].

DIE KAALKOP WAARHEID. 2007. Willem. Op: Genoeg is genoeg, kompilasie. Hoezit. (HOEZD165.) [CD].

DIE MELKTERTKOMMISIE. 2006. Wonderwoorde. Rhythm, (RR067.) [CD].

DIE SKIM. 2007. Lucky packet. Gallo. (CDRPM 1974.) [CD].

FOKOFPOLISIEKAR. 2006. Brand Suid-Afrika. Rhythm. (RR066.) [CD].

GENOEG IS GENOEG. 2007. Genoeg is genoeg, kompilasie. Hoezit. (HOEZD165.) [CD].

GOOSEN, A. 1980. Liedjieboer (LP). RPM/Agmusiek. (RPM1151.) [CD].

GOOSEN, A. 1993. Riviersonderend 21 greatest hits. Gallo. (CDGMP 40402.) [CD].

GOOSEN, A. 1996. Bushrock (of a white kaffir in Africa). Gallo. (CDGMP 40693.) [CD].

GOOSEN, A. 1998. Winde van verandering. Wildebeest/AG Musiek. (WILD 012.) [CD].

GROEN, G. 2002. Groenkitaar. Afrimusik. (Afrimusik 25.) [CD].

GROENEWALD, J. s.a. Gesig in die wind. EMI SA. (CDDCB (WL) 391.) [CD].

JACO. 2007. Sing in Afrikaans. Next Music. (NEXTCD 014.) [CD].

KERKORREL, J. 1992. Bloudruk. Tusk. (TUCD 21.) [CD].

KERKORREL, J. 1996. Ge-trans-for-meer. Tusk. (WOND 142.) [CD].

KERKORREL, J. 2000. Die ander kant. Gallo. (GWVCD 28.) [CD].

KLOPJAG. 2005. Album drie. Bowline. [CD]. 
KOMBUIS, K. 1997a. Blameer dit op apartheid. Wildebeest. (WILDE 001.) [CD]. KOMBUIS, K. 1997b. Madiba day. Wildebeest. (WILD 004. [CD].

KOMBUIS, K. 2000. Greatest hits. Gallo. (GWVCD 30.) [CD].

KOMBUIS, K. 2007. Fokkol. Op: Genoeg is genoeg, kompilasie. Hoezit. (HOEZD165.) [CD].

KOMBUIS, K. 2008. Bloedrivier. Koos Kombuis. (KKCD 02.) [CD].

KRAAMSAAL, A. 2005. Wonder jy ook soms? Cabel/Bowline. (F1000528.) [CD].

KRAAMSAAL, A. 2007. B.E.E. Op: Genoeg is genoeg, kompilasie. Hoezit. (HOEZD165.) [CD].

LE ROUX, M. 2007. Liewe Jan. Hoezit/Select. (HOEZD 117.) [CD].

LIESL, 2007. Wie doen wat? Op: Genoeg is genoeg, kompilasie. Hoezit. (HOEZD165.) [CD].

MALAN, R. 2005. Alien inboorling. Shifty. (SHIFT 1015.) [CD].

NIEMAND, H. 2007. Tot stilte. Bowline. (F1001144.) [CD].

PARAAT, P. 2007. Piet Paraat se plaat. Ramkat Music \& Entertainment. (RAMCD 002.) [CD].

PHILLIPS, J. 1993. James Philips and The Lurchers, Sunny skies. Shifty Music (SHIFT(WL) 54). [CD].

RAUCH, L. 1995. Hot Gates. Tusk. (WOND 145.) [CD].

SCHUSTER, L. 2006. Op dun Eish! EMI (SA). (CDEMIM (WL) 215.) [CD].

SMITH, P. 2002. Rooikar. Fantasia. (TOCCD180.) [CD].

SNOTKOP. 2005. Die Snotkop CD. Next music. (NEXTCD 023.) [CD].

STRYDOM, A. 1996. Vrou by die spieël. JNS. (JNSD 43.) [CD].

STRYDOM, A. 1998. Hotel Royale. JNS/SAMRO. (JNSD109.) [CD].

STRYDOM, A. 2000. Ek loop die pad al 20 jaar. JNS. (JNSD 89/AMSCD 001.) [CD].

STRYDOM, A. 2003. Verspreide donderbuie. JNS/SAMRO. (JNSD114.) [CD].

SWART, V. 1996. Die mystic boer. Rhythm. (SWART 001.) [CD].

SWART, V. 1999. Deur die donker vallei. Rhythm. (SWART 004.) [CD].

SWART, V. 2001. Boland punk. Rhythm. (SWART 005.) [CD].

SWART, V. 2002. Maanhare. Rhythm records. (SWART 006). [CD].

TAS, A. 2006. Springbok radio. EMI(SA). (CDBMIM (WLW) 206.) [CD].

VAN BLERK, B. 2006. De la Rey. Mozi/Select. (MZCD01.) [CD].

VAN NIEKERK, Z. 2007. Ramkat. LEO Musiek. (LEOCD 149.) [CD].

\section{Kernbegrippe:}

Afrikaneridentiteit

ideologiekritiek

metafooranalise

neo-Afrikaanse protesbeweging

vryheidsliedjies

\section{Key concepts:}

Afrikaner identity

freedom songs

ideology critique

metaphor analysis

neo-Afrikaner protest movement 
